第 Springer

Kew/

PLANTS PEOPLE

POSSIBILITIES

\title{
Banana Cultivation in Egypt
}

\section{Author(s): T. W. Brown}

Source: Bulletin of Miscellaneous Information (Royal Botanic Gardens, Kew), Vol. 1908, No. 3 (1908), pp. 102-105

Published by: Springer on behalf of Royal Botanic Gardens, Kew

Stable URL: http://www.jstor.org/stable/4111774

Accessed: 26-06-2016 20:49 UTC

Your use of the JSTOR archive indicates your acceptance of the Terms \& Conditions of Use, available at

http://about.jstor.org/terms

JSTOR is a not-for-profit service that helps scholars, researchers, and students discover, use, and build upon a wide range of content in a trusted digital archive. We use information technology and tools to increase productivity and facilitate new forms of scholarship. For more information about JSTOR, please contact support@jstor.org.

Springer, Royal Botanic Gardens, Kew are collaborating with JSTOR to digitize, preserve and extend access to Bulletin of Miscellaneous Information (Royal Botanic Gardens, Kew) 
Laing's specimen is precisely similar to that of Lyall, and is also sterile.

\section{Species Exclusae.}

Rhodymenia fimbriata, Hook. \& Harv. in Lond. Journ. Bot., 1847, vol. vi., p. 405.

Rhodymenia fimbriata, Hook. \& Harv., though a true Rhodophyllis, has never been published as such. It was included by J. Agardh as one of the synonyms of the New Zealand $\boldsymbol{R}$. membranacea, but it is, as shown above, quite a distinct species. There is no evidence to prove that Rhodophyllis fimbriata (nov. comb.) occurs in New Zealand.

Rhodophyllis ? angustifrons, Harv. in Hook. Fl. New Zeal., 1855, vol. ii., p. 247 ; J. Ag. Epic., 1876, p. 368 ; Laing Rev. List, 1901, p. 311.

An examination of the type specimens shows that the frond possesses the structure of the genus Callophyllis. The plant is probably an elongated form of C. coccinea, Harv.

Rhodophyllis erosa, J. Ag. Alg. Mar. Nov. Zeal., 1877, No. 182 ; Epic. 1876 , p. 695 ; Laing Rev. List, 1901, p. 341 . A species now known as Craspedocarpus erosus, Schmitz.

Rhodophyllis chathamensis, Cotton, Kew Bull., 1907, No. 2, p. 40.

This species also must be regarded as a synonym of Craspedocarpus erosus, Schmitz.

The genus Craspedocarpus was separated from Rhodophyllis by Schmitz (Syst. Uebers. Florid., p. 8; Engler Pflanzenfamilien Teil i., Abt. 2, p. 375) on account of certain structural peculiarities of the frond and cystocarp ; he refers to Callophyllis erosa, Harv., as a synonym. The original gatherings of the latter plant contain two, if not three, distinct species, viz. Callophyllis Hombroniana, Mont., Craspedocarpus erosus, Schmitz, and a third plant allied to C. Hombroniana but apparently distinct from it. The writer by not observing the double nature of the original New Zealand specimens, formed (Kew Bull. l.c.) the new species Rhodophyllis chathamensis.

\section{XVI.-BANANA CULTIVATION IN EGYPT.}

Mr. T. W. Brown, whose appointment as Secretary of the newly formed Horticultural Society at Ghizeh near Cairo was recorded last year (K.B., 1907, No. 1, p. 18), has kindly sent us the following article on the cultivation of bananas in Egypt. If the industry is at all likely to meet with the measure of success there indicated it would appear to be worthy of serious consideration.

Although bananas have long been grown in Egypt it is only within recent years that their cultivation has been carried on systematically in large plantations. This was owing greatly to the fact that all the kinds known in the country were of tall 
growth and unable, when planted in the open, to withstand the north winds which tear the leaves to shreds in winter. It is therefore the custom to plant these tall varieties in the shelter of a wall, where in most cases they are left to take care of themselves. The most common kinds grown in this way are those known locally as the "Beledi" and "Americani." The former is a blackstemmed variety of Musa sapientum, growing about 5 metres high and producing a thick, round and rather short fruit of excellent quality. The "Americani" is a form of the plantain ( $\boldsymbol{M}$. paradisiaca) common throughout the tropics. In Egypt it is usually eaten by the natives as a sweet banana without being cooked. In height and habit it resembles the "Beledi" but is easily distinguished by its light-coloured stem. The fruit is from $25-30 \mathrm{~cm}$. long and is produced in large bunches which require to be supported on forked poles to prevent the stems being broken by the weight.

'The Lady's Finger banana (another variety of $M$. sapientum) is also grown to a small extent in Egypt but the fruit is inferior in quality to that of the "Beledi" and is seldom seen in the market.

$M$. Ensete and M. rosacea are occasionally met with in gardens as ornamental plants.

From a commercial point of view however the most important species is the Chinese banana. This, although of comparatively recent introduction, is now common throughout the country. Owing to its dwarf growth it is much less subject to injury from the north wind which prevails in winter. In fact it is the introduction of this species which has made the cultivation of bananas on a large scale practicable in Egypt. No figures are available as to the area of land at present devoted to the crop, but plantations ranging from one to twenty feddans* exist in the province of Galioub, and in the vicinity of Alexandria, \&c. The amount of fruit is not however sufficient to supply even the home markets. Considerably more than $£ E$. 13,0110 worth of bananas were imported during the year 1906. The growth of the industry was arrested some three or four years ago by the attacks of an eel-worm in the plantations at Alexandria. Fortunately this pest has almost disappeared and will probably give little further trouble, if a systematic course of transplanting is followed and over-watering is avoided. On moderately light soils water is required every five or six days in summer and every nine or ten days in winter.

On good soil the plants may occupy the ground for six years.

The best growers prepare the ground for planting in the following way. After it has been ploughed, holes are dug three and a half metres apart, one metre wide and about 75 centimetres deep. A layer of coarse leaves or staule-manure 25 or 30 centimetres in thickness is placed at the bottom of the hole, which is then filled to near the top with a compost half of manure and half of soil. The land is then irrigated, and three or four days afterwards one sucker is planted in the centre of each hole. After planting, the soil is so disposed that each row of bananas stands

* One feddan $=4,200$ square metres. 
in the middle of a shallow trench about one and a half metres wide. The water is thus distributed evenly between and around the plants. Needless to say, the stronger the suckers are when planted the more quickly is the plantation established.

The best time for planting is from the middle of February until the middle of April.

In the choice of a site for a plantation the main point is to see that it is sheltered. Although there are some excellent plantations growing in the interior without shelter, and the plants quickly recover in spring from any injury received in the winter, it is nevertheless desirable that the damage may be as slight as possible ; otherwise the size of the bunches is greatly diminished. If the situation is not naturally sheltered, this is easily remedied by planting wind-breaks of the common Casuarina (C.equisetifolia). Some growers bend part of the leaves over the heart of the plant as a further protection from the slight frosts which sometimes occur in December and January.

In the matter of soil the banana is not particular, but grows equally well on yellow or on black loam, provided it is well drained and cultivated. Experiments made in growing bananas in specially prepared holes on the sandy ground at the edge of the desert have not hitherto succeeded.

The cost of establishing a plantation varies, of course, according to the distance which the manure has to be transported, and the rate of wages paid to the workmen. If we reckon $1 s$. per day as the rate of wages of the men who do the heavy work, and $7 \frac{1}{2} d$. per day for the boys who carry the manure, suckers, \&c., it works out at about $£ 1215$ s. per feddan. This is made up as follows :Labour, including ploughing, $£ 4$ 12s. $6 d$.; cost and transport of manure, $\mathfrak{f 1}$; cost of 342 suckers at $5 d$. each, $£ 72 s .6 d$. As the plants multiply rapidly the last item may figure on the estimates for the first year only, suckers for subsequent plantations being taken from that first formed. The cost of establishment is then reduced to about $£ 6$, including the expense of digging the suckers. During the first summer and winter, catch-crops of cucumbers, water melons, French beans, tomatoes, \&c., are grown between the rows, the returns from these being sufficient to cover the initial expenditure and the cost of upkeep until the bananas come into bearing. In plantations started in February and March the first bunches are cut in December, the majority of the bunches are however not ready for cutting until the following February. During the second and subsequent years it is usual to leave four fruiting stems to each plant. These should be as far as possible of different ages, so that all the fruit may not be produced at the same time.

The cultivation of bananas in Egypt is at the present time extremely lucrative. Sold on the plants, they bring from $\mathfrak{£} 80$ to $£ 120$ per feddan per year. If cut and sold by weight, when green, the minimum wholesale price is $\delta_{4}^{\frac{3}{4}} d$. per oke.* Putting the minimum weight of the bunches at four okes, four bunches to the clump per year, and 342 clumps to the feddan, a short calculation

* One oke $=2$ lbs. 12 ozs. 
will suffice to show that enormous profits are derived from this crop, even when we reckon $£ 35$ as the cost of upkeep. Counting $£ 15$ for rent, and $£ 6$ per feddan for water, the above figure allows $\mathfrak{f 1 4}$ for labour, manure and other expenses. This of course is a high estimate. If the soil is at all poor the plants require two dressings of stable-manure per year-in February and again in July. If it is rich loam one good application of manure suffices. As we have already pointed out, the amount of bananas produced in the country is not sufficient to meet the local demand. Enquiries made during the past year in various Mediterranean ports show that there is a great market for Egsptian bananas, waiting to be developed in Southern Europe. There is therefore little danger of over-production for many years to come.

The short distance and the excellent means of transport existing from Egypt to the principal European ports, would make competition with the Canary Islands comparatively easy. The quality of the fruit is superior to that from the Canaries, and was competing successfully even in France, before the appearance of the disease already referred to. The area under cultivation is increasing fast, so that the banana crop will probably be a much more important one in Egypt in the near future than it is at present.

T. W. BROWN.

\section{XVII.-DECADES KEWENSES}

\section{Plantarum Novarum in Herbario Horti RegiI CONSERVATARUM.}

\section{DECADES XLVII-XLVIII.}

461. Geunsia Havilandii, King et Gamble [Verbenaceae] ; a $G$. farinosa, Blume, caulibus foliisque fulvo-stellato-pubescentibus non farinosis etiam cymis subsessilibus differt.

Arbor? ; rami, ut inflorescentia et folia subtus, fulvo-stellatopubescentes. Folia opposita, ovata vel ovato-oblonga, apice breviter acuminata et mucronata, basi acuta vel cuneata, supra praecipue in costa scabra et hispida, subtus rugosa, stellatopubescentia et glandulis peltatis tecta, marginibus distanter denticulata, 6-15 cm. longa, 4-6 cm. lata, costa crassa prominente; nervi utrinque 9-11, nervulis transversis conspicuis inter se juncti ; petioli crassi, fulvo-hispidi, 13-17 mm. longi. Cymae axillares, pauciflorae, subsessiles, vix petiolis aequilongae; bracteae minutae, subulatae; pedicelli breves, graciles. Calyx campanulatus, intus glaber, extra strigoso-hispidus ; lobi 5, 1-1.5 $\mathrm{mm}$. longi ; fructifer persistens, complanatus. Corolla campanulata, glandulis peltatis lucidis exceptis, glabrescens; tubus $2 \cdot 5 \mathrm{~mm}$. longus ; lobi $\overline{5}$, ovati, rotundati, demum recurvi. Stamina exserta, filamentis gracilibus, antheris oblongis, $2.5 \mathrm{~mm}$. longis dorso fulvo-glandulosis. Ovarium glandulosum, depressum, stylo gracili $5 \mathrm{~mm}$. longo, stigmate breviter 5-lobato. Drupa siccitate purpureo-nigra, depressa, $3.5 \mathrm{~mm}$. diametro, 5-pyrena. 